\title{
Seaweed defence against bacteria: a poly-brominated 2-heptanone from the red alga Bonnemaisonia hamifera inhibits bacterial colonisation
}

\author{
G. M. Nylund ${ }^{1, *}$, G. Cervin ${ }^{1,2}$, F. Persson ${ }^{3}$, M. Hermansson ${ }^{3}$, P. D. Steinberg ${ }^{2}$, H. Pavia ${ }^{1}$ \\ ${ }^{1}$ Department of Marine Ecology, Göteborg University, Tjärnö Marine Biological Laboratory, 45296 Strömstad, Sweden \\ ${ }^{2}$ School of Biological Science and Centre for Marine Biofouling \& Bio-Innovation, University of New South Wales, Sydney, \\ New South Wales 2052, Australia \\ ${ }^{3}$ Department of Cell and Molecular Biology, Microbiology, Göteborg University, Box 462, 40530 Göteborg, Sweden
}

\begin{abstract}
It has previously been shown that the red alga Bonnemaisonia hamifera is less fouled by bacteria relative to co-occurring seaweeds and that surface extracts of $B$. hamifera inhibit bacterial growth at natural concentrations. In the present study, we isolated the antibacterial metabolite by bioassay-guided fractionation of extracts of $B$. hamifera using standard chromatographic methods. Nuclear magnetic resonance (NMR) spectroscopy and mass spectrometry were used for molecular identification. The antibacterial activity in the extracts was caused by a previously described polyhalogenated 2-heptanone: 1,1,3,3-tetrabromo-2-heptanone. To further investigate the role of this compound as an ecologically relevant antifoulant against bacterial colonisation, we quantified it on the surface of $B$. hamifera specimens collected in the field. Levels of 1,1,3,3-tetrabromo-2-heptanone on the surface of the algae were on average $3.6 \mu \mathrm{g} \mathrm{cm}^{-2}$. Natural surface concentrations of this secondary metabolite were used to test for growth-inhibiting effects against 18 bacterial strains isolated from red algae co-occurring with $B$. hamifera. The test indicated a phylogenetic specificity of the metabolite, and gram-positive bacteria and flavobacteria proved to be particularly sensitive. In a further test, natural surface concentrations of 1,1,3,3-tetrabromo-2-heptanone were applied to artificial panels and incubated in the sea. After 4 and $7 \mathrm{~d}$, the number of settled bacteria was significantly lower on all treated panels compared to controls. Thus, this study shows that 1,1,3,3-tetrabromo2-heptanone has an ecologically relevant role as an antifoulant against bacterial colonisation on the surface of $B$. hamifera. This study is also one of only a few to quantify natural surface concentrations of a seaweed secondary metabolite.
\end{abstract}

KEY WORDS: Marine bacteria - Bonnemaisonia hamifera $\cdot$ Chemical defence $\cdot$ Epibiotic bacteria Antimicrobial activity $\cdot$ Antifouling

\section{INTRODUCTION}

Bacteria are ubiquitous in the sea and typically occur at densities of $10^{6}$ cells ml ${ }^{-1}$ (Fenchel 1988). Thus, marine plants and animals are continuously exposed to high concentrations of bacteria, some of which can colonise living surfaces. Bacterial epibiosis on benthic macroalgae (seaweeds) can be disadvantageous for the host. For example, epiphytic bacteria can indirectly cause negative effects by providing positive settlement cues for macroscopic fouling organisms (O'Connor \& Richardson 1996, Unabia \& Hadfield 1999, Huggett et al. 2006). Furthermore, pathogenic bacteria can cause severe tissue damage in algae (Sunairi et al. 1995, Sawabe et al. 1998, Vairappan et al. 2001), or even mortality (Littler \& Littler 1995). Since seaweeds lack cell-based inducible immune responses, they must either tolerate microbial attacks, or have other means of defense. It has often been hypothesised that seaweeds have chemical defenses against bacteria (e.g. 
Lau \& Qian 1997, Kubanek et al. 2003, Engel et al. 2006), and several studies have shown that seaweeds produce compounds with antibacterial properties (Sridhar \& Vidyavathi 1991, Hellio et al. 2000, 2001). The ecological roles of these compounds are, however, often unknown. Most studies have focused on finding substances for pharmacological and antifouling applications, and only a few studies have been conducted in an ecological context by (1) investigating natural distribution and abundance of epiphytic bacteria, (2) using ecologically relevant bacteria in bioassays, and (3) testing ecologically relevant concentrations of algaderived antibacterial compounds, i.e. concentrations of metabolites that are naturally encountered by bacteria (but see Maximilien et al. 1998, Kubanek et al. 2003, Nylund et al. 2005, Paul et al. 2006a).

In a previous study on the red alga Bonnemaisonia hamifera, Nylund et al. (2005) showed that (1) crude extracts of $B$. hamifera have broad-spectrum effects against bacterial growth at volumetric concentrations, (2) lipophilic surface extract at natural concentrations per area inhibits bacterial growth, and (3) natural populations of $B$. hamifera have fewer epiphytic bacteria compared to a co-existing alga that lacks broadspectrum antibacterial metabolites. In the study by Nylund et al. (2005), the specific metabolite(s) responsible for the antibacterial activity were not identified. Previous reports showed that $B$. hamifera produces a rich variety of halogenated compounds, including 2-heptanones, 2-heptanols, acetates and acids (Siuda et al. 1975, Jacobsen \& Madsen 1978, McConnell \& Fenical 1980). Some of these metabolites show antibacterial activity (Siuda et al. 1975, McConnell \& Fenical 1979, 1980), although their ecological roles are not known.

The present study focusses on identifying the metabolite(s) responsible for the antibacterial activity in the crude extract of Bonnemaisonia hamifera and assessing their possible ecological role as natural antifoulants against bacteria. We used bioassay-guided fractionations of $B$. hamifera extracts in order to test all extractable metabolites for their antibacterial activity. We also investigated whether, and at what concentrations, the major deterrent metabolite is naturally presented to colonising bacteria by determining surface concentrations of this metabolite on algae collected in the field. We then isolated bacteria from seaweeds co-occurring with $B$. hamifera in order to test for antimicrobial effects of natural surface concentrations of the metabolite on ecologically relevant bacteria. Finally, we deployed panels treated with natural surface concentrations of the metabolite in the sea, in order to assess the effect of the metabolite on bacterial colonisation under realistic flow conditions.

\section{MATERIALS AND METHODS}

Study organism and collection of algal material. Bonnemaisonia hamifera is a filamentous red alga with a heteromorphic diplohaplontic life cycle (Dixon \& Irvine 1977, Fig. 1). The work presented in this study was done on the tetrasporangial phase (i.e. the Trailliella phase) of $B$. hamifera. This phase is very abundant along the Swedish west coast at depths of around 2 to $16 \mathrm{~m}$, where it grows as small turfs usually on other algae (Johansson et al. 1998, G. M. Nylund pers. obs.). For chemical extraction, specimens of $B$. hamifera were collected by SCUBA diving from several localities in the archipelago west of Tjärnö Marine Biological Laboratory. Several dives were necessary in order to obtain sufficient material for the extractions. After each collection, specimens of $B$. hamifera where removed from their substrate and combined. The algae were drained of excess water, weighed and stored in a freezer at $-20^{\circ} \mathrm{C}$ until used in chemical extractions ( $\leq 4$ wk after collection).

Bioassay-guided fractionation - general approach. We used bacterial growth-inhibition assays to guide our chromatographic fractionation of Bonnemaisonia hamifera extracts along polarity gradients (Fig. 2). Ini-
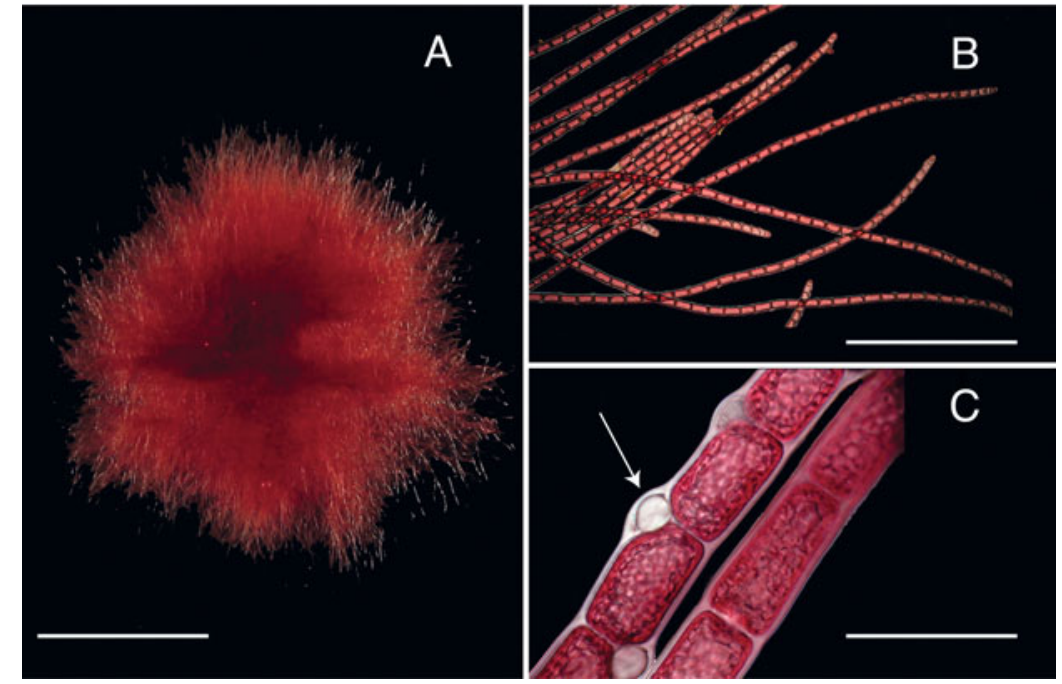

Fig. 1. Bonnemaisonia hamifera. (A) Tetrasporophytic phase, growing as small turfs, which consist of numerous sparsely branched filaments (B). Filaments are 1 cell-layer thick and have numerous gland cells located on the surface of the thallus between the vegetative cells $(\mathrm{C}$, arrow). Scale bars: $\mathrm{A}=1 \mathrm{~cm}, \mathrm{~B}=700 \mu \mathrm{m}$, $\mathrm{C}=60 \mu \mathrm{m}$ 
tial solvent partitions and bioassays of extracts were followed by further separation and purification of antimicrobial fractions using normal phase vacuum liquid chromatography. Thin-layer chromatography (TLC) on normal-phase (NP) silica gel plates was used to guide the division of fractions for subsequent bioassays. Separated compounds were visualised on TLC plates by UV absorption (254 and $365 \mathrm{~nm}$ ) and by formation of red stains after spraying with an ethanolic sulphuric solution and heating. Final purification of deterrent metabolites was performed by high performance liquid chromatography (HPLC) on NP silica. Nuclear magnetic resonance (NMR) spectrometry and mass spectrometry were used to identify deterrent metabolites.

Extraction and separation: For the initial assay of antibacterial effects of metabolites from Bonnemaisonia hamifera, $432 \mathrm{~g}$ (wet weight) of algal material was extracted in $1000 \mathrm{ml}$ methanol 3 times for $3 \mathrm{~h}$ at $4^{\circ} \mathrm{C}$. Resulting extracts were passed through a glass-fibre filter to remove particulates and the solvent was removed by rotary evaporation. This procedure was repeated with 1:1 methanol:dichloromethane, and finally dichloromethane (DCM). All of the obtained extracts were combined to a single crude extract which was then subjected to solvent partitioning following Kubanek et al. (2003). Briefly, the crude extract was partitioned between hexane and methanol/water (9:1), and the latter extract was partitioned between chloroform and methanol/water (3:2). The methanol/water fraction was further partitioned between ethyl acetate and water, and the latter extract was then portioned against $n$-butanol. The solvents were removed by rotary evaporation and the obtained extracts were tested on bacterial growth. The hexane and chloroform extracts showing the highest antibacterial activity were combined and further fractionated using silica gel flash chromatography. The combined extracts were re-dissolved in DCM and mixed with $500 \mathrm{ml}$ silica gel. The silica gel was dried at room temperature and transferred to a Büchner funnel. Six fractions were collected by eluting with $1000 \mathrm{ml}$ hexane, $1500 \mathrm{ml}$ each of $1: 10,1: 5$ and $2: 5$ ethyl

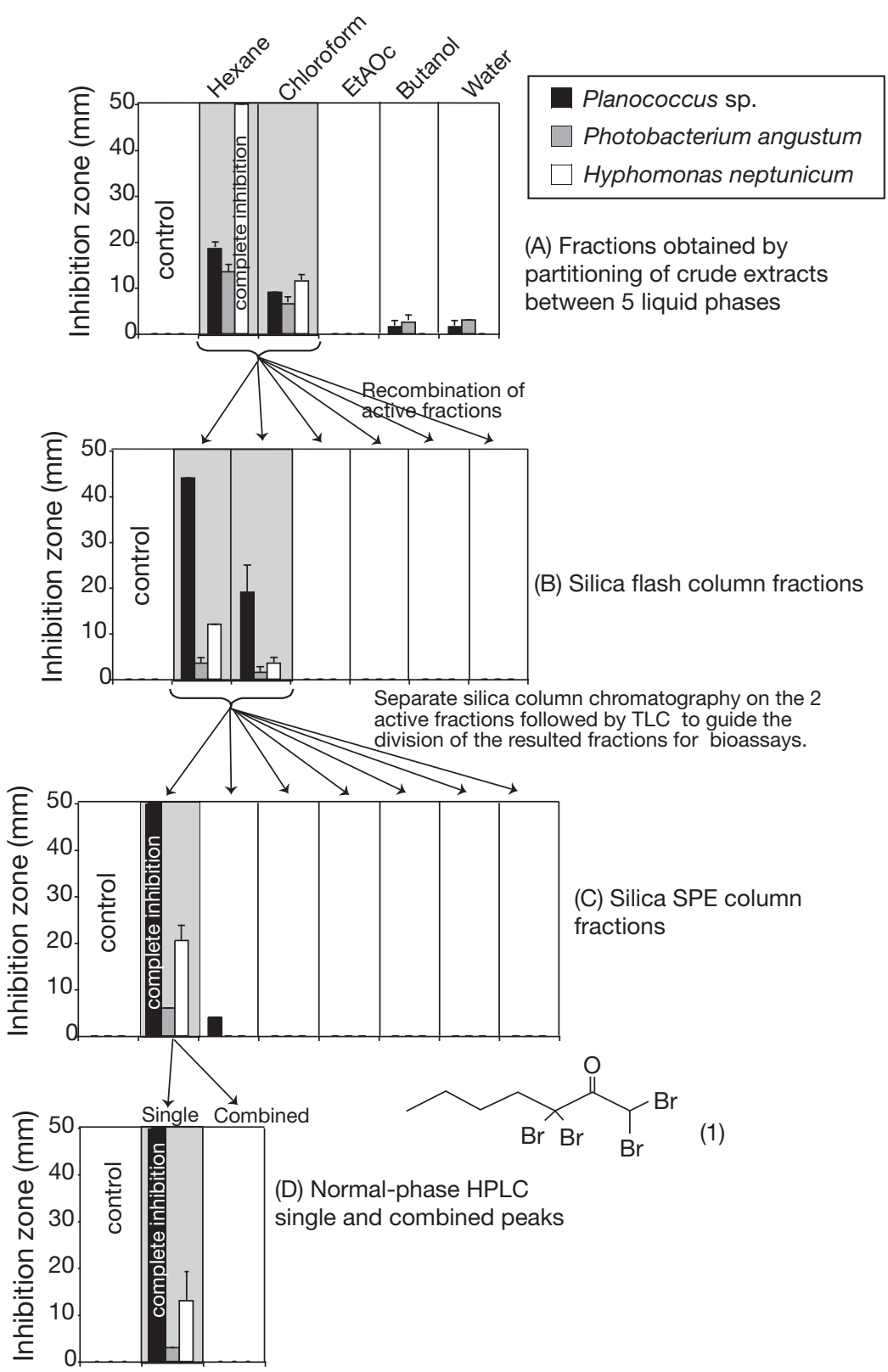

Fig. 2. Bonnemaisonia hamifera. Bioassay-guided fractionation of bacterial growth-inhibiting compounds. Three bacteria; Planococcus sp., Photobacterium angustum and Hyphomonas neptunicum were used to guide partitioning of active metabolites into different fractions. Deterrent fractions are shaded. In several assays, some fractions completely inhibited bacterial growth (i.e. A, C and D). Deterrent fraction in (D), 'single', contained the compound 1,1,3,3-tetrabromo-2-heptanone (1). The 'combined' consisted of all high performance liquid chromatography (HPLC) peaks without the 'single' peak. Data are means $+95 \%$ confidence interval, $\mathrm{n}=2$. TLC: thinlayer chromatography; SPE: solid phase extraction

acetate:hexane, $1500 \mathrm{ml}$ ethyl acetate, and $2000 \mathrm{ml}$ methanol. Two fractions eluting with hexane and 1:10 ethyl acetate:hexane inhibited bacterial growth. These fractions only partly overlapped according to TLC analyses and were further separated on NP solid 
phase extraction columns (SPE columns, $20 \mathrm{~g}$, Isolute, part no. 460-2000-F) using 1 column for each fraction. The first column, containing the more polar fraction, was eluted with hexane, 1:20, 1:10 and 1:5 ethyl acetate:hexane, and ethyl acetate $(40 \mathrm{ml}$ each). The second column was eluted with hexane, 1:10 ethyl acetate:hexane, and ethyl acetate $(120 \mathrm{ml}$ each). A total of 27 fractions were collected (based on distinct colours of the eluting extracts or a volume of $15 \mathrm{ml}$ ) from the first column, and 3 from the second. Similar fractions were pooled for subsequent bioassays, and the differentially deterrent fraction was then further separated using normal phase HPLC (Phenomenex Luna $5 \mu \mathrm{m}$ Silica (2) $100 \AA, 250 \times 4.6 \mathrm{~mm}$, isocratic elution with $100 \%$ hexane, $\left.1 \mathrm{ml} \mathrm{min}{ }^{-1}, 15 \mathrm{~min}\right)$. The molecular structure of the deterrent compound was determined by comparison of ${ }^{1} \mathrm{H},{ }^{13} \mathrm{C}$ NMR and electron impact (EI) mass spectra (McConnell \& Fenical 1980).

Bacterial assays: During the bioassay-guided fractionation of the crude extract from Bonnemaisonia hamifera, we used standard agar disc-diffusion assays to test fractions and compounds for growth inhibition of the 3 marine bacteria Hyphomonas neptunicum, Planococcus sp. and Photobacterium angustum S14, formerly known as Vibrio sp. S14 (Srinivasan et al. 1998). These strains were also used in a previous study on bacterial growth-inhibiting effects of surfaceassociated metabolites from B. hamifera (Nylund et al. 2005). Growing bacteria were maintained on nutritive agar plates (bacto marine medium 2216, Difco) and transferred to nutrient broth 24 to $48 \mathrm{~h}$ before use in assays. Extracts were re-dissolved in water, methanol, ethyl acetate, dichloromethane or hexane, depending on the polarity of extracts, and pipetted onto circular paper discs $(\mathrm{BD}$, disc volume $15 \mu \mathrm{l})$. The discs were dried in open air at room temperature and placed on nutritive agar plates, with 1 disc per plate. Control discs with only solvents added were also prepared. All extracts and compounds were tested with replication $(\mathrm{n}=2)$ at natural concentrations by volume (i.e. the amount of extract yielded from $15 \mu \mathrm{l}$ algal tissue). Assays were run at room temperature until control bacteria developed a confluent film (24 to $48 \mathrm{~h}$ ). The observed diameters of the growth-inhibition zones were measured to the nearest $1 \mathrm{~mm}$ with a ruler.

Natural surface concentrations of 1,1,3,3-tetrabromo-2-heptanone. The bioassay-guided fractionation of the crude extract from Bonnemaisonia hamifera showed that a single metabolite, 1,1,3,3-tetrabromo-2heptanone, possessed most of the antibacterial activity of the extract. To determine whether and at what concentrations this metabolite is released onto the surface of $B$. hamifera, the plant surface was extracted as previously described by Nylund et al. $(2005,2007)$. This extraction causes no visually detected damage on the gland cells (G. M. Nylund unpubl. data) where the halogenated metabolites of $B$. hamifera are presumably stored. Specimens of $B$. hamifera were collected by SCUBA diving from 2 localities (Krugglö and Yttre Vattenholmen) west of Tjärnö Marine Biological Laboratory. In the laboratory, algae were immediately removed from their substrate and stored in an aquarium with continuous seawater flow until used for extractions. Pieces of algal thalli $(n=10)$, carefully dried with precision wipes, were weighed and added to individual $10 \mathrm{ml}$ glass vials containing $2 \mathrm{ml}$ hexane and $2 \mathrm{ml}$ salt water (30 g sodium chloride in $1 \mathrm{l}$ Milli-Q water). The algal samples were vortexed for $20 \mathrm{~s}$, after which the algal material was removed from the solution. Within $3 \mathrm{~h}$ after collection, all algal samples had been extracted. The resulting extracts were put in a $-20^{\circ} \mathrm{C}$ freezer to freeze the water, and the hexane was subsequently removed from the vials and transferred to new vials. The glass vials containing the salt water were vortexed with $2 \mathrm{ml}$ hexane another 2 times, resulting in a total of 3 hexane phases for each sample. The hexane phases were pooled, evaporated under a stream of nitrogen, and the resulting surface extracts were redissolved in $1 \mathrm{ml}$ hexane containing $1 \mu \mathrm{g}$ naphthalene. The surface extracts were analysed using gas chromatography-mass spectrometry (GC-MS) with naphthalene $\left(1 \mathrm{\mu g} \mathrm{ml}^{-1}\right)$ as internal standard. Gas chromatography was performed using an Agilent 6890N gas chromatograph and a dimethylpolysiloxane coated capillary column (DB-1MS, 15 m, 0.25 mm i.d.). Helium was used as the carrier gas. All injections $(5 \mu l)$ were performed in pulsed splitless mode $(30 \mathrm{~s}$ at $80 \mathrm{psi})$ with an inlet pressure of 1 psi and a constant flow of $1 \mathrm{ml}$ $\mathrm{min}^{-1}$. A direct, deactivated inlet liner was used $(2 \mathrm{~mm}$ i.d., $78.5 \times 6.3 \mathrm{~mm}$ o.d., part no. 5183-4703). The injection port was set at $200^{\circ} \mathrm{C}$ and the GC-MS interface at $280^{\circ} \mathrm{C}$. The $\mathrm{GC}$ was set at $50^{\circ} \mathrm{C}$ for 2 min, ramped at $20^{\circ} \mathrm{C} \mathrm{min}^{-1}$ to $250^{\circ} \mathrm{C}$ and $30^{\circ} \mathrm{C} \mathrm{min}^{-1}$ to $300^{\circ} \mathrm{C}$, and then held at this temperature for $4 \mathrm{~min}$. Mass spectrometry was performed on an Agilent 5973 inert Mass Selective Detector (MSD) using EI as the ion source. Ions characteristic of 1,1,3,3-tetrabromo-2-heptanone and the internal standard (naphthalene) were monitored in scanning (SCAN) mode. Known concentrations of 1,1,3,3-tetrabromo-2-heptanone were used as standards and run at the start and end of the GC-MS analyses. Concentrations of 1,1,3,3-tetrabromo-2-heptanone in the samples were determined by calculating the ratio between peak areas of target compound and internal standard and comparing to a standard curve. Masses of 1,1,3,3-tetrabromo-2-heptanone were converted to mass per square centimetre algal surface, based on the surface area:wet weight ratio for B. hamifera. 
Growth inhibition by natural surface concentrations of 1,1,3,3-tetrabromo-2-heptanone against bacteria associated with seaweed surfaces. Isolation of bacteria: To obtain ecologically relevant bacteria for bioassays, 5 individuals each of the red algae Ceramium virgatum, Polysiphonia fucoides and Rhodomela confervoides were swabbed with sterile cotton buds for the collection of epibiotic bacteria. These algal species co-exist with Bonnemaisonia hamifera and should therefore be exposed to the same colonising bacteria. Each individual was swabbed twice, and swabs from the same species were combined and vortexed for $60 \mathrm{~s}$ in autoclaved, $0.22 \mu \mathrm{m}$-filtered seawater (FSW). Resulting bacterial suspensions were serially diluted (1 to 0.0001) in autoclaved FSW and $100 \mu \mathrm{l}$ of each dilution was streaked onto nutrient agar and incubated at room temperature under ambient light conditions. Each bacterial dilution was inoculated onto 2 low-nutrient (LN1-2) and 3 high-nutrient (HN1-3) agar media. Lownutrient media were used in addition to more traditional high-nutrient media to ensure better culturability (Jensen et al. 1996). LN1 and LN2 were composed of $17 \mathrm{~g}$ agar in $1 \mathrm{l}$ of glass-wool-filtered seawater. In addition, LN2 contained $50 \mathrm{ml}$ red algal aqueous extract, which was obtained by mixing $50 \mathrm{~g}$ freeze-dried and pulverised $C$. virgatum with $150 \mathrm{ml}$ seawater. The mixture was filtered and centrifuged, and the resulting supernatant used for the media. HN1 consisted of $15 \mathrm{~g}$ agar, $5 \mathrm{~g}$ peptone and $0.5 \mathrm{~g}$ yeast extract in $1 \mathrm{l}$ of glasswool-filtered seawater. HN2 and HN3 were similar to HN1, except that no yeast extract was used. In addition, both HN2 and HN3 lacked yeast extract. HN3 contained $50 \mathrm{ml}$ red algal extract. After 1 to $3 \mathrm{wk}$, distinguishable colonies were isolated, purified and subsequently stored at $-70^{\circ} \mathrm{C}$ in $24 \%$ glycerol.

For phylogenetic description of the isolated strains, the 16S rRNA gene was amplified and sequenced. To prepare DNA templates for PCR, 1 colony of every isolated strain was suspended and washed once in $100 \mu \mathrm{l}$ sterile Milli-Q water, whereafter the sample was boiled for $10 \mathrm{~min}$ and put on ice for $2 \mathrm{~min}$. PCR was carried out in $50 \mu \mathrm{l}$ volume using the HotStarTaq plus kit (Qiagen) according to the manufacturer's recommendations with $0.2 \mu \mathrm{M}$ of primers $27 \mathrm{~F}$ and $1492 \mathrm{R}$ (Lane 1991) and $2 \mu \mathrm{l}$ DNA template. The PCR amplification protocol consisted of an initial $5 \mathrm{~min}$ at $95^{\circ} \mathrm{C}$ to activate the DNA polymerase, denaturation at $94^{\circ} \mathrm{C}$ for $45 \mathrm{~s}$, annealing at $60^{\circ} \mathrm{C}$ for $45 \mathrm{~s}$ and elongation at $72^{\circ} \mathrm{C}$ for $1 \mathrm{~min} 45 \mathrm{~s}$ for 30 cycles, and a final elongation at $72^{\circ} \mathrm{C}$ for 7 min, using a Thermo Hybaid Px2 thermal cycler (Thermo Fisher Scientific). The amplified product was purified using the QIAquick spin columns (Qiagen). Amplified product fragment size and concentration were assessed by electrophoresis (1\% agarose, $1 \times$ TBE) using a low DNA mass ladder (Invitrogen).
Sequencing was performed with the $27 \mathrm{~F}$ primer by MWG Biotech AG, using the dideoxy chain termination/cycle sequencing technique and fluorescently labelled dideoxyoligonucleotides. A total of 63 bacterial isolates were sequenced and phylogenetic trees constructed to show the affiliation of the obtained sequences (data not shown). From these trees, 18 representative isolates encompassing all major phylogenetic clusters of the 63 isolated bacterial sequences were chosen for the growth inhibitory tests. The 18 selected sequences were compared to GenBank sequences using nucleotide BLAST (www.ncbi.nlm. nih.gov). Sequence identity was assessed using previously described criteria (Goldenberger et al. 1997). In situations where the closest match was not phylogenetically determined, the closest phylogenetically described match was chosen for identification. Similarly, in situations of several closest matches with the same degree of homology, the most phylogenetically detailed match was chosen for identification. The 18 selected sequences are available from GenBank under accession numbers EU278327 to EU278344.

Growth inhibition tests: A membrane bioassay was developed to test for growth-inhibiting effects of 1,1,3,3-tetrabromo-2-heptanone at concentrations corresponding to natural concentrations on the surface of Bonnemaisonia hamifera. To obtain enough material for bioassays, $10 \mathrm{~g}$ of 1,1,3,3-tetrabromo-2-heptanone was synthesised following McConnell and Fenical (1980), and the structure was confirmed by GC-MS, ${ }^{1} \mathrm{H}$ and ${ }^{13} \mathrm{C}$ NMR spectroscopy. The retention of $1,1,3,3-$ tetrabromo-2-heptanone on the membranes was assessed by dissolving synthesised 1,1,3,3-tetrabromo2-heptanone in hexane $\left(125 \mu \mathrm{g} \mathrm{ml}^{-1}\right)$ and applying aliquots of $100 \mu \mathrm{l}$ to $0.2 \mu \mathrm{m}$ polycarbonate membranes (25 mm diameter, polyvinylpyrrolidone-free [PVPF], GE Osmonics), mounted in sterile glass filter holders. After evaporation of the hexane (30 min), the coated membranes $(n=3)$ were placed on HN1 agar plates for $10 \mathrm{~min}$ and $4,16,42$ and $73 \mathrm{~h}$, whereafter they were extracted. Controls were membranes extracted immediately after coating with the metabolite and membranes extracted after $74 \mathrm{~h}$ to determine if storage affected the extraction yield of the metabolite. The latter were sealed in glass vials and kept in darkness at room temperature until used for extraction. All membranes were extracted 3 times in $1 \mathrm{ml}$ hexane for $10 \mathrm{~min}$ and the resulting extracts were combined for analysis.

Membranes for bioassays were coated with 1,1,3,3tetrabromo-2-heptanone according to the above procedure to give final concentrations of 0 (hexane only), $1.5,4.5$ and $13.5 \mu \mathrm{g} \mathrm{cm}{ }^{-2}$, provided that all material stayed on the membranes. One of the treatments had a higher concentration than naturally found on the sur- 
face of Bonnemaisonia hamifera, since a significant part of the compound was lost from the membranes (see 'Results'). After evaporation of the hexane (30 min), the membranes were transferred to HN1 agar plates using sterile forceps. The selected 18 bacterial strains were grown in HN1 broth until a stable stationary growth phase was attained. Droplets of $5 \mu$ of each strain were added to the membranes in serial dilutions. The assay was performed in triplicate for every bacterial strain. The agar plates with bacterial strains on membranes were incubated at $20^{\circ} \mathrm{C}$ and visually monitored for colony growth for $5 \mathrm{~d}$. An earlier preliminary test showed no effect on bacterial growth of hexane evaporated on the membranes (data not shown). Consequently, blank membranes without hexane were not included in the assays.

Field assay with natural surface concentrations of 1,1,3,3-tetrabromo-2-heptanone. The effects of 1,1,3,3-tetrabromo-2-heptanone on the colonisation of bacteria on artificial surfaces were measured in the field close to Tjärnö Marine Biological Laboratory. Preliminary studies had shown that untreated polystyrene Petri dishes retained the metabolite well in comparison with other materials (data not shown). To quantify the retention of the metabolite on the Petri dishes under realistic flow conditions, dishes were placed in the field for different time periods. Seven sets of 5 dishes were prepared by applying $0.5 \mathrm{ml}$ of synthesised 1,1,3,3-tetrabromo-2-heptanone dissolved in hexane (final concentration $4.4 \mathrm{\mu g} \mathrm{cm}^{-2}$ ) to the underside of untreated $48 \mathrm{~mm}$ polystyrene Petri dishes (diameterNunc). The underside of the dishes had a slightly raised edge, which allowed complete coverage of the surface with hexane without loss. After evaporation of the hexane ( $1 \mathrm{~h}), 5$ of the 7 sets were attached to a $2 \mathrm{~m}$ long strip with lines ( $2 \mathrm{~cm}$ between dishes) and hung from a dock for 1, 2, 4, 6 and $9 \mathrm{~d}$, whereafter they were recovered for chemical extraction. The 2 remaining sets served as controls. The first control was extracted immediately after coating with the metabolite and the second was stored at $5^{\circ} \mathrm{C}$, sealed with Parafilm for $9 \mathrm{~d}$ and subsequently extracted to determine whether storage affected the extraction yield of the metabolite. All dishes were extracted 5 times in $2 \mathrm{ml}$ hexane for $30 \mathrm{~s}$ and the resulting extracts of each were combined for analysis of 1,1,3,3-tetrabromo-2-heptanone using GC-MS as described above.

Petri dishes used to determine surface colonisation of bacteria were coated with synthesised 1,1,3,3tetrabromo-2-heptanone according to the above procedure to give final concentrations of 0 (controls), 2.8, 4.4 and $8.8 \mu \mathrm{g} \mathrm{cm}^{-2}$. The coated dishes were attached to a separate strip with lines, similar to above. A total of 60 dishes was attached to the strip $(\mathrm{n}=15$ per treatment). The array of dishes was attached to a dock and suspended at a depth of $1.5 \mathrm{~m}$. After $4(\mathrm{n}=$ $8)$ and $7 d(n=7)$, the dishes were returned directly to the laboratory in seawater for washing, staining and counting of bacterial cells. Dishes were washed 3 times with $3 \mathrm{ml}$ sterile seawater using a pipette to remove unattached bacteria, and stained for $8 \mathrm{~min}$ with $2 \mu \mathrm{g} \mathrm{ml}^{-1}$ 4,6-diamidino-2-phenylindole (DAPI) in phosphate buffer saline. Bacterial cells were then quantified via direct counts of blue fluorescent cells at a magnification of $1000 \times$ in 10 randomly chosen unit fields $\left(0.002 \mathrm{~mm}^{2}\right)$ using an epifluorescence microscope (Olympus BX 51, fluorescence mirror unit U-MNU2).

Attachment of bacteria to surfaces can be mediated by surface wettability (Wiencek \& Fletcher 1997, Ellen et al. 1998, Otto et al. 1999). Thus, it is possible that an observed effect of a chemical compound is not due to chemistry per se, but a consequence of a change in the physical characteristics of the experimental surface by the compound, or a combination of both. Therefore, we measured the surface wettability of Petri dishes with and without 1,1,3,3-tetrabromo-2-heptanone, according to the method described by Dahlgren \& Sunqvist (1981). The basis of this method is that a liquid drop put on a flat surface will have the shape of a truncated sphere. Using the formula for calculating the volume of a truncated sphere, the contact angle can be determined, as long as the diameter and the volume of the drop are known (Dahlgren \& Sunqvist 1981). We measured the diameter of $10 \mu \mathrm{l}$ water drops on polystyrene Petri dishes coated with $4.4 \mu \mathrm{g} \mathrm{cm}^{-2}$ 1,1,3,3-tetrabromo-2-heptanone as described above. Untreated dishes and dishes evaporated with $0.5 \mathrm{ml}$ hexane served as controls. The treatments were replicated 5 times, and the mean diameter of 5 drops of Milli-Q water on each Petri dish was determined using a dissecting microscope.

Statistical analyses. The results from the agar discdiffusion assays used in the bioassay-guided fractionation were analysed by calculating the $95 \%$ confidence intervals (CI) for the observed inhibition zones and subsequent examination of overlapping CIs between treatments and controls. The results from the membrane bioassays were also analysed by calculating the $\mathrm{CI}$ of the number of colonies found on coated and control membranes. For this, a Bonferroniadjusted $\alpha$-value was used (Quinn \& Keough 2002). The results from the field experiment with treated panels and the contact angle measurements were analysed by analysis of variance (1-factor ANOVA). Post-hoc comparisons were made using the StudentNewman-Keuls test (SNK-test) where required (Underwood 1997). Prior to ANOVA, homogeneity of variances was tested with Cochran's test (Underwood 1997). 


\section{RESULTS}

\section{Bioassay-guided fractionation of Bonnemaisonia hamifera extracts}

Solvent partitioning of the crude extract of Bonnemaisonia hamifera produced 2 non-polar fractions (hexane and chloroform) that strongly inhibited bacterial growth and 3 more polar fractions (ethyl acetate, $n$-butanol and water) that had a weak or no effect on the growth of the 3 tested bacteria (Fig. 2A). When the hexane and chloroform fractions were combined and further separated using silica gel flash chromatography, 2 fractions were highly inhibitory while the rest had no effect on bacterial growth (Fig. 2B). Separation of these fractions using normal phase SPE columns produced 1 fraction that contained the majority of the antibacterial activity (Fig. 2C). Further partitioning of the active fraction using normal phase HPLC yielded a single peak that strongly inhibited bacterial growth (left side of Fig. 2D). When all other portions of this fraction were combined, this mixture had no effect on bacterial growth (right side of Fig. 2D). NMR and GCMS analyses showed that the single peak consisted solely of 1,1,3,3-tetrabromo-2-heptanone (Fig. 2D).

\section{Natural surface concentrations of 1,1,3,3-tetrabromo-2-heptanone}

GC-MS analyses of the surface extracts showed that Bonnemaisonia hamifera from natural populations had 1,1,3,3-tetrabromo-2-heptanone on the surface. The surface concentrations of this metabolite on algal specimens collected from Krugglö and Yttre Vattenholmen were on average $4.4( \pm 0.49)$ and $2.8( \pm 0.65 \mathrm{SD})$ $\mu \mathrm{g} \mathrm{cm}^{-2}$, respectively.

\section{Growth inhibition by natural surface concentrations of 1,1,3,3-tetrabromo-2-heptanone against bacteria associated with seaweed surfaces}

Surface-applied 1,1,3,3-tetrabromo-2-heptanone diffused slightly from coated polycarbonate membranes placed on agar plates, with a mean of $59.8 \%$ material remaining after $73 \mathrm{~h}$ compared to the amount at the beginning of the incubation (Fig. 3). Most of the diffusion occurred within the first 10 min, with a mean of $69.3 \%$ material remaining compared to the amount at the beginning of the incubation. However, only $25.6 \%$ of the applied 1,1,3,3-tetrabromo-2-heptanone could be recovered from membranes immediately after the coating (Fig. 3). That this metabolite is volatile (Kladi et al. 2004) and readily evaporates at room temperature (authors'

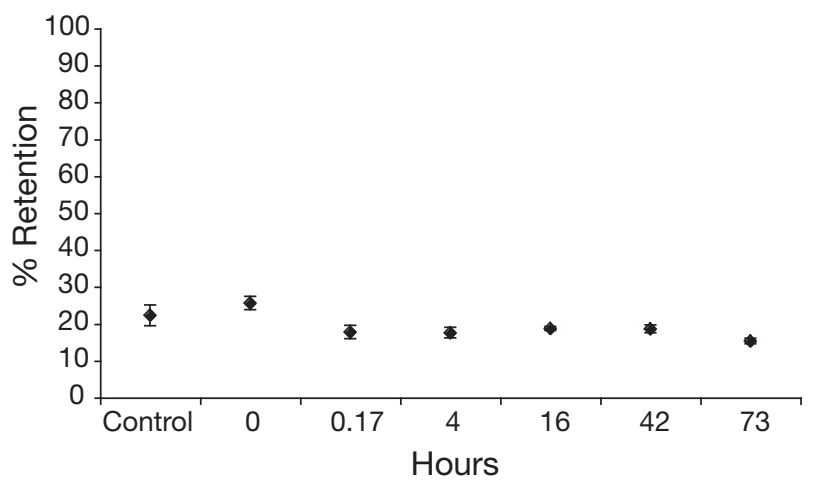

Fig. 3. Percentage retention of 1,1,3,3-tetrabromo-2-heptanone on polycarbonate membranes placed on agar plates at room temperature over $73 \mathrm{~h}$. Control membranes were kept sealed in glass vials at room temperature for $74 \mathrm{~h}$. Data are means $\pm \mathrm{SD}, \mathrm{n}=3$

pers. obs.) explains why it is most likely that a significant part of the material evaporated during the preparation of the membranes, as opposed to being bound and not extractable. Based on this reasoning and the result showing a diffusion of 1,1,3,3-tetrabromo-2-heptanone from membranes placed on agar plates, we estimated the effective concentrations in the membrane assays to be around $0.4,1.2$ and $3.5 \mu \mathrm{g} \mathrm{cm}^{-2}$.

The results of comparative sequence analysis of $16 \mathrm{~S}$ rRNA gene partial sequences of the 18 selected bacteria isolated from the surfaces of Ceramium virgatum, Polysiphonia fucoides and Rhodomela confervoides are presented in Table 1. In total, synthesised 1,1,3,3tetrabromo-2-heptanone significantly inhibited the growth of 10 of the 18 tested isolated strains (Table 2). Bacteria belonging to different phylogenetic groups varied in their sensitivity to the metabolite. The 5 gram-positive bacteria tested, all within the orders Bacillales (low GC) and Actinomycetales (high GC), were inhibited at 0.4 or $1.2 \mu \mathrm{g} \mathrm{cm}^{-2}$, while the outcome of the other tested bacteria varied. All 3 bacterial strains within Flavobacteriales were inhibited at $3.5 \mu \mathrm{g}$ $\mathrm{cm}^{-2}$. Within Rhodobacterales ( $\beta$-proteobacteria), 1 of the 3 tested strains was inhibited at $3.5 \mu \mathrm{g} \mathrm{cm}{ }^{-2}$, within Vibrionales ( $\beta$-proteobacteria), 1 of the 2 strains was inhibited at $1.2 \mu \mathrm{g} \mathrm{cm}^{-2}$, while none of the 5 strains within Alteromonadales ( $\beta$-proteobacteria) were affected by the metabolite.

\section{Field assay with natural surface concentrations of 1,1,3,3-tetrabromo-2-heptanone}

Surface-applied 1,1,3,3-tetrabromo-2-heptanone diffused gradually from coated polystyrene Petri dishes, with a mean of $39.8 \%$ of the initial material remaining after $9 \mathrm{~d}$ in the field (Fig. 4). The colonisation of bacte- 
Table 1. Identification of isolated bacteria from 3 red algae co-existing with Bonnemaisonia hamifera based on 16S rRNA gene partial sequences. CV: Ceramium virgatum; Pf: Polysiphonia fucoides; Rc: Rhodomela confervoides

\begin{tabular}{|c|c|c|c|c|c|c|}
\hline Phylum & $\begin{array}{l}\text { - Proposed identity } \\
\text { Order }\end{array}$ & Family or genus & Isolate & $\begin{array}{l}\text { Closest match } \\
\text { accession no. }\end{array}$ & $\%$ homology & $\begin{array}{l}\text { No. bases } \\
\text { called }\end{array}$ \\
\hline \multirow[t]{21}{*}{ Proteobacteria } & Alteromonadales & Alteromonas sp. & Cv1 & AB049730 & 99 & 915 \\
\hline & & Alteromonas sp. & Rc1 & DQ070782 & 99 & 916 \\
\hline & & & & AJ244756 & 99 & 916 \\
\hline & & Shewanella sp. & Cv8a & AY515438 & 99 & 926 \\
\hline & & Pseudoalteromonas sp. & Rc27 & $\mathrm{AB} 049728^{\mathrm{a}}$ & 100 & 917 \\
\hline & & & & DQ642830 & 100 & 917 \\
\hline & & & & AY028200 & 100 & 917 \\
\hline & & & & AF235119 & 100 & 917 \\
\hline & & Pseudoalteromonas sp. & Rc13 & $\mathrm{AB} 049728^{\mathrm{a}}$ & 99 & 845 \\
\hline & & & & DQ642830 & 99 & 845 \\
\hline & & & & AY028200 & 99 & 845 \\
\hline & & & & AF235119 & 99 & 845 \\
\hline & Vibrionales & Vibrio sp. & Rc11a & AM422804 & 99 & 942 \\
\hline & & Vibrio sp. & Rc28 & AY627367 & 99 & 903 \\
\hline & Rhodobacteriales & Rhodobacteraceae & Pf19 & AY082668 & 100 & 978 \\
\hline & & & & AJ810843 & 100 & 978 \\
\hline & & & & AJ810839 & 100 & 978 \\
\hline & & Sulfitobacter sp. & $\mathrm{Rc} 12 \mathrm{c}$ & EF673288 & 99 & 832 \\
\hline & & & & AY159887 & 99 & 832 \\
\hline & & Sulfitobacter sp. & Rc19b & EU016167 & 99 & 936 \\
\hline & & & & AY922234 & 99 & 936 \\
\hline \multirow[t]{3}{*}{ Bacteroidetes } & Flavobacteriales & Algibacter sp. & $\mathrm{Cv} 4$ & AY187690 & 98 & 929 \\
\hline & & Formosa sp. & Pf4 & AY771766 & 98 & 931 \\
\hline & & Flavobacterium sp. & Rc6 & AY536567 & 99 & 908 \\
\hline \multirow[t]{4}{*}{ Firmicutes } & Bacillales & Bacillus sp. & Pf10 & AM293003 & 99 & 937 \\
\hline & & & & AJ627211 & 99 & 937 \\
\hline & & Staphylococcus sp. & Pf12 & AY345395 & 99 & 885 \\
\hline & & & & D83374 & 99 & 885 \\
\hline \multirow[t]{7}{*}{ Actinobacteria } & Actinomycetales & Micrococcus sp. & Rc10a & EF491955 & 100 & 867 \\
\hline & & & & AY159885 & 100 & 867 \\
\hline & & Micrococcus sp. & Pf15 & EF451717 & 100 & 787 \\
\hline & & Dietzia sp. & Rc12a & AM697568 & 99 & 910 \\
\hline & & & & AM697544 & 99 & 911 \\
\hline & & & & AM697543 & 99 & 911 \\
\hline & & & & AY643401 ${ }^{a}$ & 99 & 910 \\
\hline
\end{tabular}

ria was significantly inhibited on dishes coated with 1,1,3,3-tetrabromo-2-heptanone at all tested concentrations compared to controls (Fig. 5), after both $4 \mathrm{~d}$ $\left(1\right.$-factor ANOVA, $F_{3,28}=48.39, \mathrm{p}<0.0001$, followed by SNK-test, $\alpha=0.05)$ and $7 \mathrm{~d}\left(1\right.$-factor ANOVA, $F_{3,24}=$ 6.36, $\mathrm{p}=0.0025$, followed by SNK-test, $\alpha=0.05$ ) in the field. No significant differences were observed between dishes with different metabolite concentrations, although there was a tendency for a dose-dependent inhibitory effect on bacterial colonisation after $7 \mathrm{~d}$. Overall, the number of bacteria on dishes was higher after 7 than after $4 \mathrm{~d}$ in the field (Fig. 5). The treatment with $4.4 \mu \mathrm{g} \mathrm{cm} \mathrm{cm}^{-2}$ 1,1,3,3-tetrabromo-2heptanone on polystyrene Petri dishes had no effect on surface wettability (based on contact angle) compared to controls (1-factor ANOVA, $F_{2,12}=1.59, \mathrm{p}=0.24$; Fig. 6).

\section{DISCUSSION}

Bioassay-guided fractionation of the crude chemical extract from Bonnemaisonia hamifera produced a single lipophilic metabolite, 1,1,3,3-tetrabromo-2heptanone, which possessed most of the antibacterial activity of the extract. This is the major halogenated compound in B. hamifera (McConnell \& Fenical 1980) and was originally described by Siuda et al. (1975). It has previously been reported that 1,1,3,3-tetrabromo2-heptanone has antimicrobial effects against fungi and bacteria (Siuda et al. 1975, McConnell \& Fenical 1979), but the possible ecological role of this metabolite has so far not been investigated. In this study, we were able to quantify the natural concentrations of 1,1,3,3-tetrabromo-2-heptanone on the algal surface. These concentrations were sufficient to inhibit the 
Table 2. Growth-inhibiting effects of 1,1,3,3-tetrabromo-2-heptanone (compound concentrations: $0.4,1.2$ and $3.5 \mu \mathrm{g} \mathrm{cm}^{-2}$ ) on bacteria isolated from 3 red algae co-existing with Bonnemaisonia hamifera. Data are average number of colonies $\pm 98.3 \% \mathrm{CI}, \mathrm{n}=3$. Bold data show significant differences from controls

\begin{tabular}{|c|c|c|c|c|c|}
\hline \multicolumn{2}{|c|}{ — Test bacteria —_ } & \multicolumn{4}{|c|}{ - Compound concentration $\left(\mu \mathrm{g} \mathrm{cm}^{-2}\right)$} \\
\hline Order & Strain & Control & 0.4 & 1.2 & 3.5 \\
\hline \multicolumn{6}{|c|}{ Alteromonadales } \\
\hline & Cv1 & $10.7 \pm 4.0$ & $12.0 \pm 5.0$ & $10.0 \pm 5.0$ & $8.7 \pm 4.4$ \\
\hline & Rc1 & $23.0 \pm 9.7$ & $28.3 \pm 7.6$ & $26.3 \pm 14.1$ & $14.0 \pm 11.8$ \\
\hline & Cv8a & $7.0 \pm 3.7$ & $6.7 \pm 7.6$ & $10.0 \pm 6.0$ & $8.0 \pm 2.4$ \\
\hline & Rc27 & $22.0 \pm 11.3$ & $21.0 \pm 17.6$ & $18.0 \pm 9.7$ & $4.3 \pm 10.4$ \\
\hline & Rc13 & $24.0 \pm 11.8$ & $23.3 \pm 12.2$ & $14.7 \pm 15.5$ & $12.0 \pm 19.2$ \\
\hline \multicolumn{6}{|c|}{ Vibrionales } \\
\hline & Rc28 & $20.3 \pm 7.9$ & $21.3 \pm 24.3$ & $0.0 \pm 0.0$ & $0.0 \pm 0.0$ \\
\hline & Rc11a & $17.7 \pm 14.0$ & $21.7 \pm 16.0$ & $22.7 \pm 20.0$ & $20.7 \pm 24.6$ \\
\hline \multicolumn{6}{|c|}{ Rhodobacteriales } \\
\hline & Pf19 & $19.5 \pm 2.1$ & $13.5 \pm 7.6$ & $17.0 \pm 1.2$ & $17.0 \pm 0.8$ \\
\hline & Rc12c & $19.3 \pm 2.1$ & $17.3 \pm 1.6$ & $28.7 \pm 10.6$ & $13.7 \pm 4.9$ \\
\hline & Rc19b & $8.0 \pm 4.1$ & $3.0 \pm 2.8$ & $3.7 \pm 2.1$ & $0.7 \pm 1.6$ \\
\hline \multicolumn{6}{|c|}{ Flavobacteriales } \\
\hline & $\mathrm{Cv} 4$ & $12.7 \pm 2.1$ & $12.7 \pm 6.8$ & $13.7 \pm 4.0$ & $5.0 \pm 3.7$ \\
\hline & Pf4 & $20.3 \pm 4.2$ & $18.0 \pm 12.3$ & $16.7 \pm 4.4$ & $0.7 \pm 0.8$ \\
\hline & Rc6 & $38.7 \pm 3.2$ & $34.7 \pm 2.9$ & $33.0 \pm 9.7$ & $21.7 \pm 9.4$ \\
\hline \multicolumn{6}{|c|}{ Bacillales } \\
\hline & Pf10 & $10.0 \pm 7.3$ & $0.0 \pm 0.0$ & $0.0 \pm 0.0$ & $0.0 \pm 0.0$ \\
\hline & Pf12 & $9.7 \pm 0.9$ & $9.5 \pm 2.0$ & $0.0 \pm 0.0$ & $0.0 \pm 0.0$ \\
\hline \multicolumn{6}{|c|}{ Actinomycetales } \\
\hline & Rc12a & $13.7 \pm 3.5$ & $0.0 \pm 0.0$ & $0.0 \pm 0.0$ & $0.0 \pm 0.0$ \\
\hline & Pf15 & $24.3 \pm 2.9$ & $23.5 \pm 0.7$ & $0.0 \pm 0.0$ & $0.0 \pm 0.0$ \\
\hline & Rc10a & $22.3 \pm 5.6$ & $20.0 \pm 1.4$ & $0.0 \pm 0.0$ & $0.0 \pm 0.0$ \\
\hline
\end{tabular}

ural surface concentrations of 1,1,3,3tetrabromo-2-heptanone imply that this metabolite can inhibit bacterial colonisation of the algal thallus. Thus, this study shows that 1,1,3,3-tetrabromo-2heptanone has an ecologically relevant role as a natural antifoulant.

Only a few studies have measured surface concentrations of secondary metabolites on algal surfaces. de Nys et al. (1998) showed that the mean total surface concentration of natural products (palisadin A and aplysistatin) on the red alga Laurencia obtusa was less than $1 \mathrm{ng} \mathrm{cm}^{-2}$. Studies on the red alga Delisea pulchra have shown that halogenated furanones are presented on the algal surface at concentrations ranging from 100 to $500 \mathrm{ng} \mathrm{cm}{ }^{-2}$, which are sufficiently high to deter ecologically relevant bacteria (de Nys et al. 1998, Maximilien et al. 1998, Dworjanyn et al. 1999). In contrast to these previous findings, surface-associated secondary metabolites are found in much higher concentrations on Bonnemaisonia hamifera. The surface concentrations of 1,1,3,3-tetrabromo-2heptanone on $B$. hamifera specimens collected from 2 localities were on average 2.8 and $4.4 \mu \mathrm{g} \mathrm{cm}^{-2}$. This large difference in surface concentrations among species may be explained by differences in the cellular localisation of secondary metabolites among the seaweeds. Secondary metabolites in Laurencia species are localised in intracellular vesicles known as 'corp en

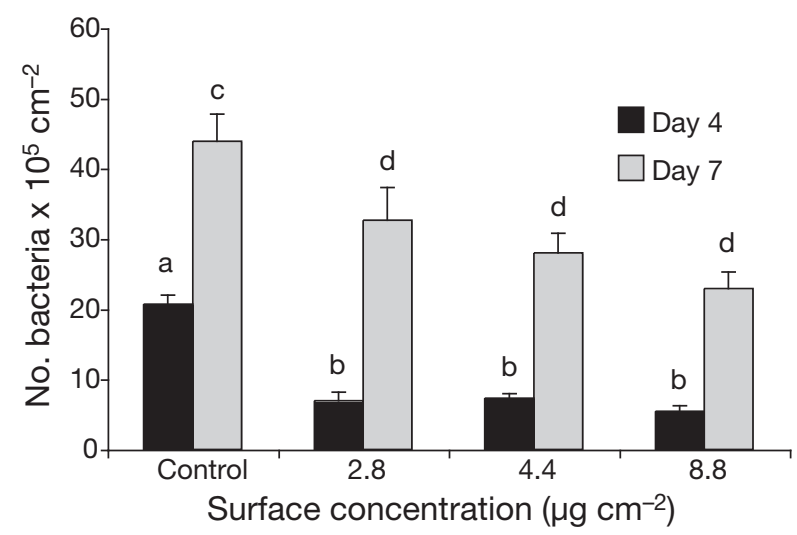

Fig. 5. Bacterial abundances on polystyrene Petri dishes coated with different concentrations of 1,1,3,3-tetrabromo-2heptanone after 4 and $7 \mathrm{~d}$ in the field. Data are means $+\mathrm{SE}, \mathrm{n}=$ 8 and 7 for dishes hung out for 4 and 7 d, respectively. Data with significant differences are indicated by different letters above the bars (Student-Newman-Keuls-tests, $\alpha=0.05$ ) 


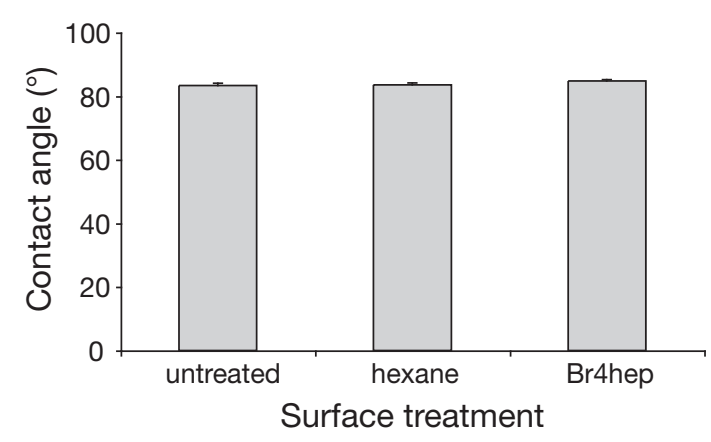

Fig. 6. Surface wettabilities (as contact angles) for untreated polystyrene Petri dishes and dishes treated with hexane and 1,1,3,3-tetrabromo-2-heptanone (Br4hep; $\left.4.4 \mathrm{\mu g} \mathrm{cm}^{-2}\right)$. Data are means $+\mathrm{SE}, \mathrm{n}=5$

cerise' (Young et al. 1980). The vesicles occur only within the outer cortex of the plant and there is no information about possible mechanisms that can release the metabolites contained within the vesicles to the surface of the plant (Hay et al. 1987). Halogenated furanones in D. pulchra are stored in specialised vesicular cells known as gland cells (Dworjanyn et al. 1999). These cells occur both within the thallus and at the algal surface, from where they release furanones onto the surface (de Nys et al. 1998, Dworjanyn et al. 1999). $B$. hamifera, which belongs to the same family as $D$. pulchra (Bonnemaisoniaceae), also has gland cells located at the surface of the alga between the vegetative cells (Fritsch 1945; Fig. 1C). It has been suggested that 1,1,3,3-tetrabromo-2-heptanone and the other halogenated compounds from $B$. hamifera are stored in these gland cells (Wolk 1968, McConnell \& Fenical 1980). This suggestion is supported by pilot studies in which we (1) detected 1,1,3,3-tetrabromo-2-heptanone in the gland cells using Raman spectroscopy and (2) observed a large decrease in the total plant content of 1,1,3,3-tetrabromo-2-heptanone coinciding with a significant reduction in gland cell size for specimens grown in the absence of bromide in the culture medium (G. M. Nylund et al. unpubl. data). The high concentration of surface-associated metabolites on $B$. hamifera may be explained by the fact that the gland cells are very numerous and always in contact with the surface of the thallus (Fig. 1C).

The phylogenetic identification of the bacteria isolated from the 3 red algae corresponds well with other identified bacterial isolates obtained from marine surfaces and red algae (Beleneva \& Zhukova 2006, Lee et al. 2007). Results from the membrane bioassays, in which concentrations found naturally on the surface of Bonnemaisonia hamifera were tested against these ecologically relevant bacteria, point towards selective effects of 1,1,3,3-tetrabromo-2-heptanone on bacterial growth. In these assays, only gram-positive bacteria (within Bacillales and Actinomycetales) and flavobacteria were generally inhibited, and few bacterial strains within the other tested taxa were affected. These results seem to contradict those of a previous study by Nylund et al. (2005), in which volumetric concentrations of $B$. hamifera crude extracts had broad-spectrum effects on bacterial growth. In that study, the growth of 9 out of 11 bacterial strains, from similar bacterial phylogenetic groups as in the present study, was inhibited. A probable explanation for this discrepancy is, however, that the study by Nylund et al. (2005) most likely tested much higher concentrations of 1,1,3,3-tetrabromo-2-heptanone than the present study by using whole cell extracts in the bioassays. It is also possible that the whole cell extract used in the Nylund et al. (2005) study could have contained other metabolites with growth-inhibiting effects on bacteria, as suggested by McConnell \& Fenical (1979). The selective effects of 1,1,3,3-tetrabromo-2-heptanone shown in the present study imply that this metabolite may affect not only the numbers of epiphytic bacteria, but also the community composition on $B$. hamifera. The finding that some bacteria were insensitive to 1,1,3,3-tetrabromo-2-heptanone in the membrane bioassays is in accordance with the observations that some bacteria colonised the metabolite-coated field panels, although to a significantly lower degree than the uncoated ones, and that $B$. hamifera from natural populations is not free of surface-associated bacteria (Nylund et al. 2005). However, to assess the effect of 1,1,3,3-tetrabromo-2heptanone on bacterial community composition, phylogenetic analysis of the epiphytic community on natural populations of $B$. hamifera using molecular methods is necessary.

The bioassay-guided fractionation of the crude extracts from Bonnemaisonia hamifera resulted in a few other antibacterial fractions besides those containing 1,1,3,3-tetrabromo-2-heptanone. This may indicate that metabolites other than 1,1,3,3-tetrabromo-2heptanone also have chemical defence functions against bacteria. At least 18 halogenated secondary metabolites have been described from $B$. hamifera, some with documented in vitro antimicrobial activities (Jacobsen \& Madsen 1978, McConnell \& Fenical 1979). However, only 1,1,3,3-tetrabromo-2-heptanone was detected in the surface extracts of $B$. hamifera collected from the field. This finding implies that other lipophilic halogenated secondary metabolites are either not present on the surface of the algal thallus, or are only found in very low concentrations. Thus, it is very likely that 1,1,3,3-tetrabromo-2-heptanone, which is by far the major halogenated compound in B. hamifera (McConnell \& Fenical 1980), is the most important defence metabolite against bacterial colonisation. 
From a chemical ecology point of view, Bonnemaisoniaceae is an intriguing seaweed family. Its members are very rich in secondary metabolites (McConnell \& Fenical 1979, Kladi et al. 2004), several of which have been shown to have ecological roles as defence metabolites (Steinberg et al. 2001, Williamson et al. 2004, Wright et al. 2004, Paul et al. 2006a,b). It can be noted that most studies documenting the ecological roles of seaweed metabolites as antifoulants against microbial colonisation have involved members of the Bonnemaisoniaceae (i.e. Maximilien et al. 1998, Nylund et al. 2005, Paul et al. 2006a, this study). Interestingly, members of this family all have gland cells that are either in direct contact with the algal surface (Dixon \& Irvine 1977, Dworjanyn et al. 1999, Fig. 1C), or are connected to the surface by other means (Paul et al. 2006a). This feature enables delivery and release of metabolites to the surface, and its presence in the members of the Bonnemaisoniaceae may indicate that chemical defence against bacteria is a common feature of this algal family.

In conclusion, this study has shown that the antibacterial activity of Bonnemaisonia hamifera extracts is mainly caused by the production of 1,1,3,3-tetrabromo-2-heptanone. This metabolite is released to the surface of the alga at concentrations that inhibit colonisation by naturally occurring bacteria. Thus, this study demonstrates an ecological function of 1,1,3,3-tetrabromo-2-heptanone as a natural antifoulant against bacteria.

Acknowledgements. We thank N. Kumar for helping with NMR analyses and T. Charlton for chemical advice. This research was supported by The Swedish Research Council through contract 621-2004-2658, by FORMAS through contracts 21.0-2003-1119 and 210-2005-249, and by MARICE, a strategic research platform in marine chemical ecology at Göteborg University.

\section{LITERATURE CITED}

Beleneva IA, Zhukova NV (2006) Bacterial communities of some brown and red algae from Peter the Great Bay, the Sea of Japan. Microbiology 75:348-357

Dahlgren C, Sunqvist T (1981) Phagocytosis and hydrophobicity: a method of calculating contact angles based on the diameter of sessile drops. J Immunol Methods 40:171-179

$>$ de Nys R, Dworjanyn SA, Steinberg PD (1998) A new method for determining surface concentrations of marine natural products on seaweeds. Mar Ecol Prog Ser 162:79-87

Dixon PS, Irvine LM (1977) Seaweeds of the British Isles, Vol 1, Rhodophyta. Part 1: Introduction, Nemaliales, Gigartinales. The Natural History Museum, London

$>$ Dworjanyn SA, De Nys R, Steinberg PD (1999) Localisation and surface quantification of secondary metabolites in the red alga Delisea pulchra. Mar Biol 133:727-736

Ellen RP, Wikstrom M, Grove DA, Song MJ, Elwing H (1998) Polar adhesion of Treponema denticola on wettability gradient surfaces. Colloids Surf B: Biointerfaces 11:177-186

Engel S, Puglisi MP, Jensen PR, Fenical W (2006) Antimicro- bial activities of extracts from tropical Atlantic marine plants against marine pathogens and saprophytes. Mar Biol 149:991-1002

Fenchel T (1988) Marine plankton food chains. Annu Rev Ecol Syst 19:19-38

Fritsch FE (1945) The structure and reproduction of the algae, Vol 2. Phaeophyceae, Rhodophyceae, Myxophyceae and a foreword. Cambridge University Press, Cambridge

Goldenberger D, Künzli A, Vogt P, Zbinden R, Altwegg M (1997) Molecular diagnosis of bacterial endocarditis by broad-range PCR amplification and direct sequencing. J Clin Microbiol 35:2733-2739

Hay ME, Fenical W, Gustafson K (1987) Chemical defense against diverse coral-reef herbivores. Ecology 68: 1581-1591

Hellio C, Bremer G, Pons AM, Le Gal Y, Bourgougnon N (2000) Inhibition of the development of microorganisms (bacteria and fungi) by extracts of marine algae from Brittany, France. Appl Microbiol Biotechnol 54:543-549

Hellio C, De La Broise D, Dufosse L, Le Gal Y, Bourgougnon $N$ (2001) Inhibition of marine bacteria by extracts of macroalgae: potential use for environmentally friendly antifouling paints. Mar Environ Res 52:231-247

Huggett MJ, Williamson JE, de Nys R, Kjelleberg S, Steinberg PD (2006) Larval settlement of the common Australian sea urchin Heliocidaris erythrogramma in response to bacteria from the surface of coralline algae. Oecologia 149: $604-619$

Jacobsen N, Madsen JO (1978) Halogenated metabolites including brominated 2-heptanols and 2-heptyl acetates from the tetrasporophyte of the red alga Bonnemaisonia hamifera. Tetrahedron Lett 19:3065-3068

Jensen PR, Kauffman CA, Fenical W (1996) High recovery of culturable bacteria from the surfaces of marine algae. Mar Biol 126:1-7

Johansson G, Eriksson BK, Pedersen M, Snoeijs P (1998) Long-term changes of macroalgal vegetation in the Skagerrak area. Hydrobiologia 385:121-138

> Kladi M, Vagias C, Roussis V (2004) Volatile halogenated metabolites from marine red algae. Phytochem Rev 3: 337-366

Kubanek J, Jensen PR, Keifer PA, Sullards MC, Collins DO, Fenical W (2003) Seaweed resistance to microbial attack: a targeted chemical defense against marine fungi. Proc Natl Acad Sci USA 100:6916-6921

Lane DJ (1991) 16S/23S rRNA sequencing. In: Stackebrandt E, Goodfellow M (eds) Nucleic acid techniques in bacterial systematics. John Wiley \& Sons, Chichester, p 115-175

Lau SCK, Qian PY (1997) Phlorotannins and related compounds as larval settlement inhibitors of the tube-building polychaete Hydroides elegans. Mar Ecol Prog Ser 159: 219-227

Lee OO, Yang LH, Li X, Pawlik JR, Qian PY (2007) Surface bacterial community, fatty acid profile, and antifouling activity of two congeneric sponges from Hong Kong and the Bahamas. Mar Ecol Prog Ser 339:25-40

> Littler MM, Littler DS (1995) Impact of clod pathogen on pacific coral reefs. Science 267:1356-1360

> Maximilien R, de Nys R, Holmstrom C, Gram L and others (1998) Chemical mediation of bacterial surface colonisation by secondary metabolites from the red alga Delisea pulchra. Aquat Microb Ecol 15:233-246

McConnell OJ, Fenical W (1979) Antimicrobial agents from the marine red algae of the family Bonnemaisoniacea. In: Hoppe HA, Levring T, Tanaka Y (eds) Marine algae in pharmaceutical science. Walter de Gruyter, Berlin, p $479-500$ 
McConnell OJ, Fenical W (1980) Halogen chemistry of the red alga Bonnemaisonia. Phytochemistry 19:233-247

Nylund GM, Cervin G, Hermansson M, Pavia H (2005) Chemical inhibition of bacterial colonization by the red alga Bonnemaisonia hamifera. Mar Ecol Prog Ser 302:27-36

Nylund GM, Gribben PE, de Nys R, Steinberg PD, Pavia H (2007) Surface chemistry versus whole-cell extracts: antifouling tests with seaweed metabolites. Mar Ecol Prog Ser 329:73-84

O'Connor NJ, Richardson DL (1996) Effects of bacterial films on attachment of barnacle (Balanus improvisus Darwin) larvae: laboratory and field studies. J Exp Mar Biol Ecol 206:69-81

> Otto K, Elwing H, Hermansson M (1999) The role of type 1 fimbriae in adhesion of Escherichia coli to hydrophilic and hydrophobic surfaces. Colloids Surf B: Biointerfaces 15: 99-111

Paul NA, de Nys R, Steinberg PD (2006a) Chemical defence against bacteria in the red alga Asparagopsis armata: linking structure with function. Mar Ecol Prog Ser 306: 87-101

Paul NA, de Nys R, Steinberg PD (2006b) Seaweed-herbivore interactions at a small scale: direct tests of feeding deterrence by filamentous algae. Mar Ecol Prog Ser 323:1-9

Quinn G, Keough M (2002) Experimental design and data analysis for biologists. Cambridge University Press, Cambridge

Sawabe T, Makino H, Tatsumi M, Nakano K and others (1998) Pseudoalteromonas bacteriolytica sp. nov., a marine bacterium that is the causative agent of red spot disease of Laminaria japonica. Int J Syst Bacteriol 48:769-774

Siuda JF, VanBlaricom GR, Shaw PD, Johnson RD, White RH, Hager LP, Rinehart KL (1975) 1-Iodo-3,3-dibromo-2heptanone, 1,1,3,3-tetrabromo-2-heptanone, and related compounds from the red alga Bonnemaisonia hamifera. J Am Chem Soc 97:937-938

Sridhar KR, Vidyavathi N (1991) Antimicrobial activity of seaweeds. Acta Hydrochim Hydrobiol 19:455-496

Srinivasan S, Östling J, Charlton T, de Nys R, Takayama K, Kjelleberg S (1998) Extracellular signal molecule(s) in-

Editorial responsibility: Joseph Pawlik, Wilmington, North Carolina, USA volved in the carbon starvation response of marine Vibrio sp. strain S14. J Bacteriol 180:201-209

Steinberg PD, de Nys R, Kjelleberg S (1998) Chemical inhibition of epibiota by Australian seaweeds. Biofouling 12: $227-244$

Steinberg P, de Nys R, Kjelleberg S (2001) Chemical mediation of surface colonization. In: McClintock JB, Baker BJ (eds) Marine chemical ecology. CRC Press, Boca Raton, FL, p 355-87

Sunairi M, Tsuchiya H, Tsuchiya T, Omura Y and others (1995) Isolation of a bacterium that causes Anaaki disease of the red algae Porphyra yezoensis. J Appl Bacteriol 79:225-229

> Unabia CRC, Hadfield MG (1999) Role of bacteria in larval settlement and metamorphosis of the polychaete Hydroides elegans. Mar Biol 133:55-64

Underwood AJ (1997) Experiments in ecology: their logical design and interpretation using analysis of variance. Cambridge University Press, Cambridge

- Vairappan CS, Suzuki M, Motomura T, Ichimura T (2001) Pathogenic bacteria associated with lesions and thallus bleaching symptoms in the Japanese kelp Laminaria religiosa Miyabe (Laminariales, Phaeophyceae). Hydrobiologia 445:183-191

Wiencek KM, Fletcher M (1997) Effects of substratum wettability and molecular topography on the initial adhesion of bacteria to chemically defined substrata. Biofouling 11: 293-311

Williamson JE, Carson DG, de Nys R, Steinberg PD (2004) Demographic consequences of an ontogenetic shift by a sea urchin in response to host plant chemistry. Ecology 85:1355-1371

Wolk C (1968) Role of bromine in the formation of the refractile inclusions of the vesicle cells of the Bonnemaisoniaceae (Rhodophyta). Planta 78:371-378

Wright JT, de Nys R, Poore AGB, Steinberg PD (2004) Chemical defense in a marine alga: heritability and the potential for selection by herbivores. Ecology 85:2946-2959

> Young DN, Howard BM, Fenical W (1980) Subcellular localization of brominated secondary metabolites in the red alga Laurencia snyderae. J Phycol 16:182-185

Submitted: November 22, 2007; Accepted: May 15, 2008

Proofs received from author(s): September 22, 2008 